\title{
Sulfurimonas paralvinellae sp. nov., a novel mesophilic, hydrogen- and sulfur-oxidizing chemolithoautotroph within the Epsilonproteo- bacteria isolated from a deep-sea hydrothermal vent polychaete nest, reclassification of Thiomicrospira denitrificans as Sulfurimonas denitrificans comb. nov. and emended description of the genus Sulfurimonas
}

Correspondence

Ken Takai

kent@jamstec.go.jp
The GenBank/EMBL/DDBJ accession number for the $16 \mathrm{~S}$ rRNA gene sequence of strain $\mathrm{GO} 25^{\top}$ is $\mathrm{AB} 252048$.

An electron micrograph of a cell of Sulfurimonas paralvinellae $\mathrm{GO} 25^{\top}$ and graphs showing the effects of temperature, $\mathrm{pH}$ and $\mathrm{NaCl}$ concentration on the growth of the strain are available as supplementary figures in IJSEM Online.
Ken Takai, Masae Suzuki, Satoshi Nakagawa, Masayuki Miyazaki, Yohey Suzuki, Fumio Inagaki and Koki Horikoshi

Subground Animalcule Retrieval (SUGAR) Program, Japan Agency for Marine-Earth Science and Technology, 2-15 Natsushima-cho, Yokosuka 237-0061, Japan

A novel mesophilic bacterium, strain $\mathrm{GO}^{2} 5^{\top}$, was isolated from a nest of hydrothermal vent polychaetes, Paralvinella sp., at the Iheya North field in the Mid-Okinawa Trough. Cells were motile short rods with a single polar flagellum. Growth was observed between 4 and $35^{\circ} \mathrm{C}$ (optimum $30{ }^{\circ} \mathrm{C} ; 13-16 \mathrm{~h}$ doubling time) and between $\mathrm{pH} 5.4$ and 8.6 (optimum $\mathrm{pH} 6 \cdot 1$ ). The isolate was a facultatively anaerobic chemolithoautotroph capable of growth using molecular hydrogen, elemental sulfur or thiosulfate as the sole energy source, carbon dioxide as the sole carbon source, ammonium or nitrate as the sole nitrogen source and elemental sulfur, thiosulfate or yeast extract as the sole sulfur source. Strain $\mathrm{GO} 25^{\top}$ represents the first deep-sea epsilonproteobacterium capable of growth by both hydrogen and sulfur oxidation. Nitrate or molecular oxygen (up to $10 \%$ partial pressure) could serve as the sole electron acceptor to support growth. Metabolic products of nitrate reduction shifted in response to the electron donor provided. The $\mathrm{G}+\mathrm{C}$ content of genomic DNA was 37.6 mol\%. Phylogenetic analysis based on 16S rRNA gene sequences indicated that the novel isolate belonged to the genus Sulfurimonas and was most closely related to Sulfurimonas autotrophica OK10 $10^{\top}(96 \cdot 3 \%$ sequence similarity). DNA-DNA hybridization demonstrated that the novel isolate could be differentiated genotypically from Sulfurimonas autotrophica $\mathrm{OK}_{10} 0^{\top}$. On the basis of the physiological and molecular properties of the novel isolate, the name Sulfurimonas paralvinellae sp. nov. is proposed, with strain $\mathrm{GO}_{2}{ }^{\top}(=\mathrm{JCM}$ $13212^{\top}=$ DSM $\left.17229^{\top}\right)$ as the type strain. Thiomicrospira denitrificans DSM $1251^{\top}\left(=\right.$ ATCC $^{2}$ $33889^{\top}$ ) is phylogenetically associated with Sulfurimonas autotrophica OK $10^{\top}$ and Sulfurimonas paralvinellae $\mathrm{GO} 25^{\top}$. Based on the phylogenetic relationship between Thiomicrospira denitrificans DSM $1251^{\top}$, Sulfurimonas autotrophica $\mathrm{OK} 10^{\top}$ and Sulfurimonas paralvinellae $\mathrm{GO}_{25}{ }^{\top}$, we propose the reclassification of Thiomicrospira denitrificans as Sulfurimonas denitrificans comb. nov. (type strain DSM $1251^{\top}=$ ATCC $33889^{\top}$ ). In addition, an emended description of the genus Sulfurimonas is proposed.
An increasing number of previously uncultivated members of the Epsilonproteobacteria from deep-sea hydrothermal environments have been isolated and characterized recently (Alain et al., 2002; Campbell et al., 2001; Inagaki et al., 2003, 2004; Miroshnichenko et al., 2002, 2004; Nakagawa et al., 2005a, b, c; Takai et al., 2003, 2004a, c, 2005a; Voordeckers et al., 2005). All the deep-sea epsilonproteobacterial strains 
described so far can be classified into the following groups with respect to their energy yielding process: (i) sulfuroxidizing, (ii) hydrogen-oxidizing and (iii) both hydrogenand formate-oxidizing. Sulfurimonas autotrophica $\mathrm{OK} 10^{\mathrm{T}}$ (Inagaki et al., 2003) and Sulfurovum lithotrophicum $42 \mathrm{BKT}^{\mathrm{T}}$ (Inagaki et al., 2004) are sulfur-oxidizing chemolithoautotrophs that utilize reduced sulfur compounds such as thiosulfate and elemental sulfur $\left(S^{0}\right)$. The hydrogen-oxidizing group consists of Hydrogenimonas thermophila EP1-55-1\% ${ }^{\mathrm{T}}$ (Takai et al., 2004c), Thioreductor micantisoli BKB25Ts- $\mathrm{Y}^{\mathrm{T}}$ (Nakagawa et al., 2005a), Nitratifractor salsuginis E9I37-1 ${ }^{\mathrm{T}}$ (Nakagawa et al., 2005b), Nitratiruptor tergarcus MI55- $1^{\mathrm{T}}$ (Nakagawa et al., 2005b), Lebetimonas acidiphila Pd55 $5^{\mathrm{T}}$ (Takai et al., 2005a), Caminibacter mediatlanticus TB-2 ${ }^{\mathrm{T}}$ (Voordeckers et al., 2005) and Caminibacter profundus $\mathrm{CR}^{\mathrm{T}}$ (Miroshnichenko et al., 2004). For Nautilia lithotrophica $525^{\mathrm{T}}$ (Miroshnichenko et al., 2002) and Caminibacter hydrogeniphilus AM1116 ${ }^{\mathrm{T}}$ (Alain et al., 2002), formate can serve as the sole energy source in addition to molecular hydrogen. Several as yet undescribed strains potentially belonging to the genus Sulfurospirillum, isolated from nests of the tubedwelling polychaete Alvinella pompejana, also represent the hydrogen- and formate-oxidizing group (Campbell et al., 2001). Although previously described deep-sea members of the Epsilonproteobacteria gain energy by either hydrogen- or sulfur-oxidation, Nakagawa et al. (2005c) demonstrated that many of the epsilonproteobacterial isolates within group B and group F from a variety of deep-sea hydrothermal habitats have versatile energy metabolisms capable of using both molecular hydrogen and reduced sulfur compounds as energy sources.

Strain $\mathrm{GO} 25^{\mathrm{T}}$ (previously designated strain GO25-1) was isolated from a nest of a deep-sea hydrothermal vent polychaete (Paralvinella sp.) at a sulfide mound called North Big Chimney (NBC) (Takai et al., 2004b) at the Iheya North field in the Mid-Okinawa Trough (Takai et al., 2003). Preliminary phylogenetic and physiological characterizations have suggested that this strain is phylogenetically related to Sulfurimonas autotrophica $\mathrm{OK} 10^{\mathrm{T}}$, but its energy metabolism is considerably different from that of Sulfurimonas autotrophica $\mathrm{OK} 10^{\mathrm{T}}$ (Takai et al., 2003; Nakagawa et al., 2005c). Strain $\mathrm{GO} 25^{\mathrm{T}}$ can be characterized by its ability to utilize both molecular hydrogen and reduced sulfur compounds as the sole energy source (Nakagawa et al., 2005c). This type of energy metabolism might be a key not only to elucidate genetic and biochemical aspects of epsilonproteobacterial energy metabolism, but also to understand the ecophysiological roles of these bacteria, which dominate a variety of deep-sea hydrothermal environments. The taxonomic and physiological properties of strain $\mathrm{GO} 25^{\mathrm{T}}$ are reported in this study. The aim of this study was to establish the basis for further comparative genetic and biochemical investigations and for in situ ecophysiological surveys.

\section{Sample collection, enrichment and purification}

Strain $\mathrm{GO} 25^{\mathrm{T}}$ was isolated from a polychaete nest colonizing NBC as previously described (Nakagawa et al., 2005c; Takai et al., 2003, 2004b). After successful enrichment with MMJHS medium, as described by Takai et al. (2003), strain $\mathrm{GO} 25^{\mathrm{T}}$ was obtained as a pure culture using the dilution-toextinction technique (Takai \& Horikoshi, 2000). MMJHS medium contained $1 \mathrm{~g}$ of each of $\mathrm{NaHCO}_{3}, \mathrm{Na}_{2} \mathrm{~S}_{2} \mathrm{O}_{3} .5 \mathrm{H}_{2} \mathrm{O}$ and $\mathrm{NaNO}_{3}, 30 \mathrm{~g} \mathrm{~S}^{0}$ and $10 \mathrm{ml}$ vitamin solution (Balch et al., 1979) per litre of MJ synthetic seawater (Takai et al., 2003). The purity was confirmed routinely by microscopic observation and by repeated partial sequencing of the $16 \mathrm{~S}$ rRNA gene using several primers (Lane, 1991). Strain $\mathrm{GO} 25^{\mathrm{T}}$ was routinely cultivated with MMJHS (thiosulfate-minus) medium, which was MMJHS medium without thiosulfate, with a gas phase of $80 \% \mathrm{H}_{2}$ and $20 \% \mathrm{CO}_{2}(200 \mathrm{kPa}$ ) (Takai et al., 2003).

Sulfurimonas autotrophica $\mathrm{OK} 10^{\mathrm{T}}$ (Inagaki et al., 2003) was isolated by our laboratory and Thiomicrospira denitrificans DSM $1251^{\mathrm{T}}$ (Timmer-ten Hoor, 1975) was purchased from the Deutsche Sammlung von Mikroorganismen und Zellkulturen. These strains were routinely cultivated at their optimal conditions as previously described (Inagaki et al., 2003; Timmer-ten Hoor, 1975).

\section{Morphology}

Cells were observed under a phase-contrast microscope (BX51; Olympus) with the SPOT RT Slider CCD camera system (Diagnostic Instruments). Gram-staining was performed by using a Gram-stain kit (Wako). Transmission electron microscopy of negatively stained cells was carried out as described by Zillig et al. (1990). Cells grown in MMJHS (thiosulfate-minus) medium at $30{ }^{\circ} \mathrm{C}$ that were in the mid-exponential phase of growth were used for microscopic observation. Cells of strain $\mathrm{GO} 25^{\mathrm{T}}$ were Gramnegative short rods, which were about $0 \cdot 6-0 \cdot 8 \mu \mathrm{m}$ in width, $1.5-2.5 \mu \mathrm{m}$ in length and motile with a polar flagellum (see Supplementary Fig. S1 in IJSEM Online). Spore formation was not observed under any culture conditions. These morphological features of strain $\mathrm{GO} 25^{\mathrm{T}}$ are similar to those of the previously described members of the Epsilonproteobacteria (Table 1).

\section{Growth characteristics}

Strain $\mathrm{GO} 25^{\mathrm{T}}$ was routinely cultivated in MMJHS (thiosulfate-minus) medium. To prepare the medium, all the components other than the vitamin solution, elemental sulfur and $\mathrm{NaHCO}_{3}$ were dissolved in distilled deionized water and the $\mathrm{pH}$ was adjusted to around $6 \cdot 0$ with $\mathrm{HCl}$ before autoclaving. After autoclaving, concentrated solutions of vitamins, $\mathrm{NaHCO}_{3}$ and elemental sulfur were added to the medium under gas purging of $80 \% \mathrm{H}_{2}$ and $20 \% \mathrm{CO}_{2}$ and the $\mathrm{pH}$ was readjusted to $6 \cdot 0$ with $\mathrm{HCl}$ unless otherwise noted. These solutions were separately sterilized by filtration and the elemental sulfur was sterilized by autoclaving at $95^{\circ} \mathrm{C}$ for $3 \mathrm{~h}$ three times. The medium was dispensed at $20 \%$ of the total bottle (Schott Glaswerke) or tube (Iwaki Glass) volume and containers were tightly sealed with a butyl rubber stopper under a gas phase of $80 \% \mathrm{H}_{2}$ and $20 \%$ 
Table 1. Comparison of characteristics of Sulfurimonas paralvinellae $\mathrm{GO} 25^{\top} \mathrm{sp}$. nov. and related type strains

Taxa: 1, Sulfurimonas paralvinellae GO25 $5^{\mathrm{T}}$ sp. nov. (data from this study; Suzuki et al., 2005; Takai et al., 2005b); 2, Sulfurimonas autotrophica OK10 ${ }^{\mathrm{T}}$ (Inagaki et al., 2003; Takai et al., 2005b); 3, Sulfurimonas (Thiomicrospira) denitrificans DSM 1251 ${ }^{\mathrm{T}}$ (Timmer-ten Hoor, 1975; Kuenen et al., 1991; Brinkhoff et al., 2005; Hügler et al., 2005); 4, Nitratifractor salsuginis E9I37-1 ${ }^{\mathrm{T}}$ (Nakagawa et al., 2005b; Takai et al., 2005b). ND, Not determined. All four strains grow under microaerobic conditions. All strains possess key genes and enzymes for the reductive TCA cycle.

\begin{tabular}{|c|c|c|c|c|}
\hline Characteristic & 1 & 2 & 3 & 4 \\
\hline Cell shape & Rod & Rod & $\operatorname{Rod}^{*}$ & Rod \\
\hline \multicolumn{5}{|l|}{ Growth: } \\
\hline Temperature range $\left({ }^{\circ} \mathrm{C}\right)$ & $4-35$ & $10-40$ & ND & $30-40$ \\
\hline Temperature optimum $\left({ }^{\circ} \mathrm{C}\right)$ & 30 & $23-26$ & 22 & 37 \\
\hline $\mathrm{pH}$ range & $5 \cdot 4-8 \cdot 6$ & $5 \cdot 0-9 \cdot 0$ & ND & $5 \cdot 6-7 \cdot 6$ \\
\hline pH optimum & $6 \cdot 1$ & $6 \cdot 5$ & 7 & 7 \\
\hline $\mathrm{NaCl}$ requirement & + & + & - & + \\
\hline Maximum $\mathrm{O}_{2}$ concentration $(\%)$ & 10 & 15 & $0 \cdot 5$ & $0 \cdot 6$ \\
\hline Electron donors & $\mathrm{H}_{2}, \mathrm{~S}^{0}, \mathrm{~S}_{2} \mathrm{O}_{3}^{2-}$ & $\mathrm{S}^{0}, \mathrm{~S}_{2} \mathrm{O}_{3}^{2-}$ & $\mathrm{HS}^{-}, \mathrm{S}_{2} \mathrm{O}_{3}^{2-}$ & $\mathrm{H}_{2}$ \\
\hline Electron acceptors & $\mathrm{NO}_{3}^{-}, \mathrm{O}_{2}$ & $\mathrm{O}_{2}$ & $\mathrm{NO}_{3}^{-}, \mathrm{NO}_{2}^{-}, \mathrm{O}_{2}$ & $\mathrm{NO}_{3}^{-}, \mathrm{O}_{2}$ \\
\hline Products of nitrate reduction & $\mathrm{NO}_{2}^{-}, \mathrm{N}_{2} \mathrm{O}, \mathrm{N}_{2}$ & None & $\mathrm{N}_{2}$ & $\mathrm{~N}_{2}$ \\
\hline Hydrogenase activity & + & - & $\mathrm{ND}$ & + \\
\hline Hydrogenase genes & + & - & ND & + \\
\hline Sulfite oxidoreductase activity & + & + & ND & - \\
\hline Major fatty acids & $\begin{array}{c}\mathrm{C}_{18: 1}(37 \%) \\
\mathrm{C}_{16: 0}(25 \%) \\
\mathrm{C}_{16: 1}(22 \%)\end{array}$ & $\begin{array}{c}\mathrm{C}_{16: 1}(45 \%) \\
\mathrm{C}_{16: 0}(37 \%) \\
\mathrm{C}_{18: 1}(9 \%)\end{array}$ & ND & $\begin{array}{cc}\mathrm{C}_{18: 1} & (42 \%), \\
\mathrm{C}_{16: 1} & (31 \%), \\
\mathrm{C}_{16: 0} & (24 \%)\end{array}$ \\
\hline DNA G $+\mathrm{C}$ content $(\mathrm{mol} \%)$ & $37 \cdot 6$ & $35 \cdot 2$ & 36 & $35 \cdot 5$ \\
\hline
\end{tabular}

${ }^{*}$ Cells of Thiomicrospira denitrificans DSM $1251^{\mathrm{T}}$ have previously been reported to be spiral, but in this study straight to slightly curved, short rods were observed in the exponential growth phase.

$\mathrm{CO}_{2}$ at $200 \mathrm{kPa}$. All experiments described below were conducted in duplicate.

Growth of strain $\mathrm{GO} 25^{\mathrm{T}}$ was measured by direct cell counting after staining with $4^{\prime}$,6-diamidino-2-phenylindole (DAPI) (Porter \& Feig, 1980) using a phase-contrast microscope (BX51; Olympus). The cultures were grown in $100 \mathrm{ml}$ glass bottles (Schott Glaswerke) each containing $20 \mathrm{ml}$ medium, with shaking (100 r.p.m.) in a temperaturecontrolled dry oven. With MMJHS (thiosulfate-minus) medium, strain $\mathrm{GO} 25^{\mathrm{T}}$ grew over a temperature range of about $4-35^{\circ} \mathrm{C}$, showing optimal growth at $30^{\circ} \mathrm{C}$. The generation time at $30^{\circ} \mathrm{C}, \mathrm{pH} 6 \cdot 1$, was about $13-16 \mathrm{~h}$ (see Supplementary Fig. S2a in IJSEM Online). When the effect of $\mathrm{pH}$ on growth was tested at $30^{\circ} \mathrm{C}$, the $\mathrm{pH}$ of the MMJHS (thiosulfate-minus) medium was adjusted to various values with $10 \mathrm{mM}$ acetate/acetic acid buffer ( $\mathrm{pH} 3-5)$, MES ( $\mathrm{pH}$ 5-6), PIPES ( $\mathrm{pH} 6-7)$, HEPES ( $\mathrm{pH} 7-7 \cdot 5)$ or Tris ( $\mathrm{pH} 8-9 \cdot 5)$ at room temperature (Supplementary Fig. S2b). Growth occurred between $\mathrm{pH} 5 \cdot 4$ and $8 \cdot 6$, with optimum growth at about pH 6.1 (Supplementary Fig. S2b). No growth was observed at $\mathrm{pH} 4 \cdot 9$ or $9 \cdot 2$. The $\mathrm{pH}$ of the medium was found to be stable during growth. When grown in MMJHS (thiosulfate-minus) medium with variable concentrations of $\mathrm{NaCl}$, strain $\mathrm{GO} 25^{\mathrm{T}}$ grew over an $\mathrm{NaCl}$ concentration range of 12 to $50 \mathrm{~g} \mathrm{l}^{-1}$, with optimum growth at $30 \mathrm{~g} \mathrm{l}^{-1}$ at $30^{\circ} \mathrm{C}$ and $\mathrm{pH} 6 \cdot 1$ (Supplementary Fig. S2c). In general, the effects of temperature, $\mathrm{pH}$ and $\mathrm{NaCl}$ concentration on the growth of strain $\mathrm{GO} 25^{\mathrm{T}}$ are similar to those observed for Sulfurimonas autotrophica $\mathrm{OK} 10^{\mathrm{T}}$ (Table 1). However, growth of strain $\mathrm{GO} 25^{\mathrm{T}}$ is much slower than that of Sulfurimonas autotrophica $\mathrm{OK} 10^{\mathrm{T}}$ 
and the ability to grow at $4{ }^{\circ} \mathrm{C}$ is a novel physiological feature of strain $\mathrm{GO} 25^{\mathrm{T}}$ compared with all other previously described deep-sea epsilonproteobacteria (Table 1).

Heterotrophic growth of strain $\mathrm{GO} 25^{\mathrm{T}}$ was tested in MMJHS (thiosulfate-minus) medium without $\mathrm{NaHCO}_{3}$ under a gas phase of $100 \% \mathrm{H}_{2}(200 \mathrm{kPa})$, containing each of the following potential organic carbon sources: $0 \cdot 1 \%(\mathrm{w} / \mathrm{v})$ yeast extract, $0 \cdot 1 \%(\mathrm{w} / \mathrm{v})$ tryptone, $0 \cdot 1 \%(\mathrm{w} / \mathrm{v})$ Casamino acids, $5 \mathrm{mM}$ formate, $5 \mathrm{mM}$ acetate, $5 \mathrm{mM}$ glycerol, $0.025 \%(\mathrm{v} / \mathrm{v})$ methanol, $0 \cdot 05 \%(\mathrm{v} / \mathrm{v})$ ethanol, $0 \cdot 1 \%(\mathrm{v} / \mathrm{v})$ 2-propanol, $5 \mathrm{mM}$ citrate, $5 \mathrm{mM}$ L-tartrate, $5 \mathrm{mM}$ fumarate, $5 \mathrm{mM}$ succinate, $5 \mathrm{mM}$ propionate, $5 \mathrm{mM}$ L-malate, $5 \mathrm{mM}$ L-lactate, $5 \mathrm{mM}$ oxalate, $5 \mathrm{mM}$ pyruvate, $5 \mathrm{mM}$ of each of 20 L-amino acids, $0 \cdot 1 \%(\mathrm{w} / \mathrm{v})$ D-glucose, $0 \cdot 1 \%$ $(\mathrm{w} / \mathrm{v})$ D-galactose, $0.1 \%(\mathrm{w} / \mathrm{v})$ sucrose, $0.1 \%(\mathrm{w} / \mathrm{v})$ D-fructose, $0 \cdot 1 \%(\mathrm{w} / \mathrm{v})$ D-lactose, $0 \cdot 1 \%(\mathrm{w} / \mathrm{v})$ D-maltose and $0 \cdot 1 \%(\mathrm{w} / \mathrm{v})$ starch. Strain GO $25^{\mathrm{T}}$ was not able to grow heterotrophically using $\mathrm{H}_{2}$ and $\mathrm{S}^{0}$ as potential energy sources and nitrate as an electron acceptor. Utilization of these organic compounds as an alternative energy source instead of $\mathrm{H}_{2}$ and $\mathrm{S}^{0}$ was also examined in MMJHS (thiosulfate-minus) medium containing each of the organic compounds described above under a gas phase of $80 \% \mathrm{~N}_{2}$ and $20 \% \mathrm{CO}_{2}(200 \mathrm{kPa})$. Under these conditions, none of the organic compounds sustained the growth of strain $\mathrm{GO} 25^{\mathrm{T}}$ as the energy source.

In an attempt to determine electron acceptors for growth of strain $\mathrm{GO} 25^{\mathrm{T}}$, each of the potential electron acceptors, such as sulfite $(2 \mathrm{mM}$ and $10 \mathrm{mM})$, thiosulfate $(10 \mathrm{mM})$, tetrathionate $(10 \mathrm{mM})$, nitrate $(10 \mathrm{mM})$, nitrite $(1 \mathrm{mM}$ and $5 \mathrm{mM})$, ferric citrate $(20 \mathrm{mM})$, selenate $(5 \mathrm{mM})$, arsenate (5 mM), fumarate $(10 \mathrm{mM})$ and $\mathrm{O}_{2}(0 \cdot 5,1,2,3,5,10,15$ and $20 \%$ partial pressure) was tested with $\mathrm{H}_{2}$ and $\mathrm{S}^{0}$ as the electron donors. Nitrate and $\mathrm{O}_{2}(0 \cdot 5-10 \%$ partial pressure $)$ supported growth as the sole electron acceptor while nitrate provided a better cell yield than the optimal concentrations of $\mathrm{O}_{2}(0.5$ and $1 \%$ partial pressure $)$.

Strain $\mathrm{GO} 25^{\mathrm{T}}$ did not grow in the absence of $\mathrm{S}^{0}$ with MMJHS (thiosulfate-minus) medium under a gas phase of $80 \% \mathrm{H}_{2}$ and $20 \% \mathrm{CO}_{2}$ at $200 \mathrm{kPa}$. This might have two different explanations: (i) $\mathrm{H}_{2}$ does not serve as the energy source and $S^{0}$ is absolutely required as the sole energy source or (ii) $\mathrm{H}_{2}$ serves as the energy source but $\mathrm{S}^{0}$ is absolutely required as the sulfur source. In an attempt to determine a sulfur source for growth of strain GO25 ${ }^{\mathrm{T}}$, potential sources such as sulfate $(5 \mathrm{mM})$, sulfite $(2 \mathrm{mM})$, thiosulfate $(5 \mathrm{mM})$, $\mathrm{S}^{0}(1 \%, \mathrm{w} / \mathrm{v})$, sodium sulfide $(2 \mathrm{mM})$, cysteine hydrochloride $(2 \mathrm{mM})$ and yeast extract $(0 \cdot 1 \% \mathrm{w} / \mathrm{v})$ were examined in MMJHS (thiosulfate-minus) medium in which sulfur compounds were removed and replaced with the chloride salts under a gas phase of $80 \% \mathrm{H}_{2}$ and $20 \%$ $\mathrm{CO}_{2}$ at $200 \mathrm{kPa}$. Strain $\mathrm{GO} 25^{\mathrm{T}}$ grew using $\mathrm{H}_{2}$ as the energy source only when thiosulfate, $S^{0}$ or yeast extract was provided as the sole sulfur source. No growth occurred when strain $\mathrm{GO} 25^{\mathrm{T}}$ was transferred directly from the culture grown in MMJHS (thiosulfate-minus) medium under a gas phase of $80 \% \mathrm{H}_{2}$ and $20 \% \mathrm{CO}_{2}$ at $200 \mathrm{kPa}$ to $\mathrm{H}_{2}$-free MMJHS (thiosulfate-minus) medium under a gas phase of $80 \% \mathrm{~N}_{2}$ and $20 \% \mathrm{CO}_{2}$ at $200 \mathrm{kPa}$. However, after acclimatization of strain $\mathrm{GO} 25^{\mathrm{T}}$ to the medium with decreasing partial pressures of $\mathrm{H}_{2}$, the strain was eventually able to grow on $\mathrm{S}^{0}$ or thiosulfate as the sole electron donor using nitrate or $\mathrm{O}_{2}$ as an electron acceptor. Thus, $\mathrm{H}_{2}, \mathrm{~S}^{0}$ or thiosulfate can serve as the sole electron donor for growth of strain $\mathrm{GO} 25^{\mathrm{T}}$.

Potential trace nutrients required for growth, such as selenite, tungstate and vitamins, were examined in MMJHS (thiosulfate-minus) medium in the absence of the tested compounds and the nitrogen source for growth $\left(\mathrm{NH}_{4} \mathrm{Cl}\right.$, $\mathrm{NaNO}_{2}, \mathrm{~N}_{2}, \mathrm{NaNO}_{3}$ or yeast extract) was also examined. Selenium, tungsten and vitamins were not required for growth. Isolate $\mathrm{GO} 25^{\mathrm{T}}$ utilized ammonium, nitrate or yeast extract as a nitrogen source, but could not utilize nitrite or molecular nitrogen.

Isolate $\mathrm{GO} 25^{\mathrm{T}}$ is the first deep-sea epsilonproteobacterium capable of utilizing both $\mathrm{H}_{2}$ and reduced sulfur compounds as energy sources (Table 1 ). The possible requirement of $S^{0}$ as a sulfur source for growth is reported for Nitratifractor salsuginis E9I37- $1^{\mathrm{T}}$ (Nakagawa et al., 2005b). However, $S^{0}$ is not absolutely required and no oxidation of $S^{0}$ occurred during the growth of Nitratifractor salsuginis E9I37- ${ }^{\mathrm{T}}$ (Nakagawa et al., 2005b).

Since strain $\mathrm{GO} 25^{\mathrm{T}}$ utilizes $\mathrm{S}^{0}$ as both an energy and sulfur source, it is very interesting that the strain is able to grow with the oxidation of $\mathrm{H}_{2}$ and/or $\mathrm{S}^{0}$. The time-course of the oxidation of $\mathrm{H}_{2}$ and $\mathrm{S}^{0}$ and the concomitant reduction of nitrate during growth of strain $\mathrm{GO} 25^{\mathrm{T}}$ was examined with MMJHS (thiosulfate-minus) medium in the absence of $\mathrm{NH}_{4} \mathrm{Cl}$ under a varying partial pressure of $\mathrm{H}_{2}$. The experiment was conducted at $30^{\circ} \mathrm{C}$ and $\mathrm{pH} 6 \cdot 1$ using $100 \mathrm{ml}$ bottles. The concentrations of $\mathrm{H}_{2}, \mathrm{~N}_{2}$ and $\mathrm{N}_{2} \mathrm{O}$ in the gas phase during growth were measured using a gas chromatograph (Micro GC CP2002; GL Sciences) and anions such as chloride, nitrate, nitrite, thiosulfate, sulfite and sulfate were determined by HPLC using a Shim-pack IC column (Shimadzu). Production of ammonium ions was also checked by using Nessler's reagent (Allen et al., 1974). When strain $\mathrm{GO} 25^{\mathrm{T}}$ was grown with excess amounts of both $\mathrm{H}_{2}(80 \%$ and $20 \%, 2$ atm., corresponding to 82 and $20.5 \mathrm{mM})$ and $S^{0}(1 \% \mathrm{w} / \mathrm{v}$, corresponding to $300 \mathrm{mM})$, nitrate was reduced to nitrite and $\mathrm{N}_{2} \mathrm{O}$ (Fig. 1a). During growth, $\mathrm{H}_{2}$ was consumed predominantly and the oxidation of $S^{0}$ to thiosulfate and sulfate remained at a low level (Fig. 1a). For growth with $\mathrm{H}_{2}$-limited or -free media, the oxidation of $\mathrm{S}^{0}$ was significantly increased (Fig. 1b, c). Under $\mathrm{H}_{2}$-limited ( $1 \%$ and $0 \cdot 2 \%, 2$ atm., corresponding to 1 and $0 \cdot 2 \mathrm{mM}$ ) conditions, $S^{0}$ was oxidized to thiosulfate and sulfate and nitrate was reduced to nitrite, $\mathrm{N}_{2} \mathrm{O}$ and $\mathrm{N}_{2}$ (Fig. 1b). However, during growth in the absence of $\mathrm{H}_{2}$, only sulfate and $\mathrm{N}_{2}$ were detected as the products of $S^{0}$ oxidation and nitrate reduction, respectively (Fig. 1c). In all cases, no ammonification was detected and the $\mathrm{pH}$ of the medium was stable at $\mathrm{pH} 6 \cdot 1$ during growth. Based on final 
(a)

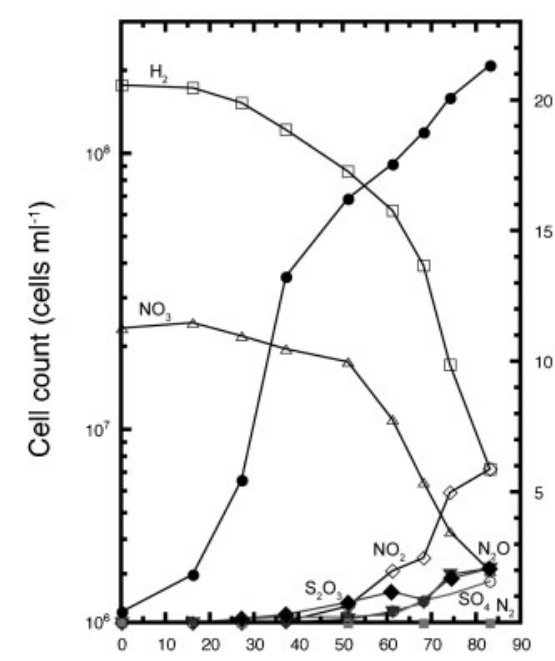

(b)

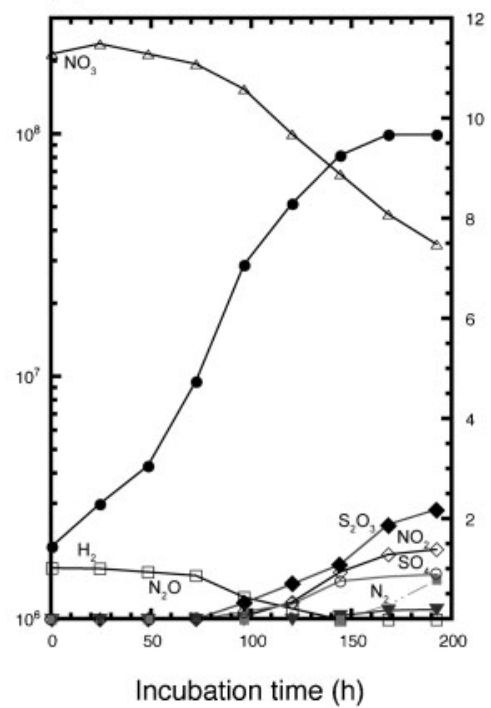

(c)

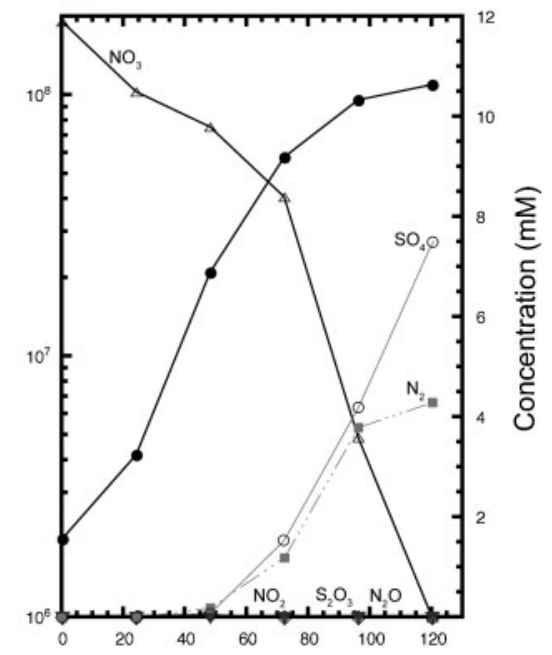

Fig. 1. Time-courses of the oxidation of $\mathrm{H}_{2}$ and $\mathrm{S}^{0}$ and the reduction of nitrate during growth of strain $\mathrm{GO} 25^{\top}$. (a) Redox reactions during growth with excess amounts of both $\mathrm{H}_{2}(20.5 \mathrm{mM})$ and $\mathrm{S}^{0}(300 \mathrm{mM})$ in the medium. (b) Redox reactions during growth under $\mathrm{H}_{2}$-limited ( $1 \mathrm{mM}$ ) conditions. (c) Redox reactions during growth in $\mathrm{H}_{2}$-free MMJHS (thiosulfate-minus) medium under a gas phase of $80 \% \mathrm{~N}_{2}$ and $20 \% \mathrm{CO}_{2}$ at $200 \mathrm{kPa}$. Filled circles indicate the cell number during the growth.

cell yields and the consumption of the electron donors, in the cases of growth under $\mathrm{H}_{2}$-abundant and $\mathrm{H}_{2}$-free conditions, both $\mathrm{H}_{2}$ and $\mathrm{S}^{0}$ gave a similar efficiency $\left(1 \cdot 4 \times 10^{7}\right.$ cells $\mu \mathrm{mol}^{-1}$ ) for cellular yield of strain $\mathrm{GO} 25^{\mathrm{T}}$, while $\mathrm{H}_{2}$ resulted in a higher growth rate. These results strongly suggest that $\mathrm{H}_{2}$ is a better energy source for faster growth of strain $\mathrm{GO} 25^{\mathrm{T}}$ than $\mathrm{S}^{0}$ in in vitro experiments and that oxidation of different electron donors is coupled with different extents of nitrate reduction. The biochemical and molecular mechanism of the electron donor-dependent shift in reduction of the electron acceptor (switching of nitrate reduction pathways by different electron donors) should be further investigated.

Sensitivity of strain $\mathrm{GO} 25^{\mathrm{T}}$ to antibiotics (at 50 and $100 \mu \mathrm{g} \mathrm{ml}^{-1}$ ) such as chloramphenicol, streptomycin, kanamycin, ampicillin and rifampicin was tested at $30^{\circ} \mathrm{C}$. Strain $\mathrm{GO} 25^{\mathrm{T}}$ was sensitive to all the antibiotics tested at a concentration of $50 \mu \mathrm{g} \mathrm{ml}^{-1}$.

\section{Fatty acid analysis}

Cellular fatty acid composition was analysed from cells grown in MMJHS (thiosulfate-minus) medium at $30^{\circ} \mathrm{C}$ in the late-exponential growth phase as reported previously (Suzuki et al., 2005). The major cellular fatty acids of strain $\mathrm{GO} 25^{\mathrm{T}}$ were $\mathrm{C}_{18: 1}(37 \%), \mathrm{C}_{16: 0}(25 \%), \mathrm{C}_{16: 1}(22 \%)$, $3-\mathrm{OH} \mathrm{C} \mathrm{C}_{14: 0}(7 \%), \mathrm{C}_{14: 0}(5 \%)$ and $\mathrm{C}_{18: 0}(4 \%)$ (Suzuki et al., 2005). This composition was similar to that of Nitratifractor salsuginis E9137- $1^{\mathrm{T}}$ (Nakagawa et al., 2005b) rather than to that of Sulfurimonas autotrophica $\mathrm{OK} 10^{\mathrm{T}}$ (Inagaki et al., 2003).

\section{Nucleic acid analyses}

Genomic DNA of strain GO25 ${ }^{\mathrm{T}}$ was prepared as described by Marmur \& Doty (1962). The DNA G $+C$ content was determined by direct analysis of deoxyribonucleotides on HPLC (Tamaoka \& Komagata, 1984). The DNA G+C content of strain $\mathrm{GO} 25^{\mathrm{T}}$ was $37 \cdot 6 \mathrm{~mol} \%$, which is similar to those of Sulfurimonas autotrophica $\mathrm{OK}_{10}^{\mathrm{T}}(35 \cdot 2 \mathrm{~mol} \%)$ (Inagaki et al., 2003), Thiomicrospira denitrificans DSM $1251^{\mathrm{T}}$ (36.0 mol\%) (Brinkhoff et al., 2005; Kuenen et al., 1991; Timmer-ten Hoor, 1975) and Thioreductor micantisoli BKB25Ts- $Y^{\mathrm{T}}(37 \cdot 2 \mathrm{~mol} \%)$ (Nakagawa et al., 2005a).

The $16 \mathrm{~S}$ rRNA gene was amplified by PCR using primers Bac 27F and 1492R (DeLong, 1992; Lane, 1991) as described previously (Takai et al., 2001). The nearly complete sequence $(1445 \mathrm{bp})$ of the $16 \mathrm{~S}$ rRNA gene from strain GO25 ${ }^{\mathrm{T}}$ was directly sequenced in both strands using the dideoxynucleotide chain-termination method with a DNA sequencer (Model 3100; Perkin Elmer). The 16S rRNA gene sequence was subjected to a gapped BLAST search (Altschul et al., 1997; Benson et al., 1998) and was found to be most closely related to the sequences of a gill symbiont of the deep-sea vent gastropod Alviniconcha sp. (97·4\% sequence similarity) from the Manus Basin (Urakawa et al., 2005), Sulfurimonas autotrophica $\mathrm{OK}_{10}^{\mathrm{T}}(96 \cdot 3 \%)$ (Inagaki et al., 2003) and Thiomicrospira denitrificans DSM $1251^{\mathrm{T}}(93 \cdot 1 \%)$ (Brinkhoff et al., 2005; Kuenen et al., 1991; Timmer-ten Hoor, 1975). The 16S rRNA gene sequence of Sulfurimonas autotrophica $\mathrm{OK} 10^{\mathrm{T}}$ showed $93 \cdot 3 \%$ similarity to that of Thiomicrospira denitrificans DSM $1251^{\mathrm{T}}$. The sequence was manually aligned with a subset of 16S rRNA gene sequences 
from GenBank according to secondary structure using ARB (Ludwig et al., 2004). Phylogenetic analyses were restricted to unambiguously aligned nucleotide positions. Evolutionary distance matrix analysis (using the Jukes-Cantor correlation method) and neighbour-joining analysis were performed using the PHYLIP package (http://evolution.genetics. washington.edu/phylip.html). Maximum-likelihood analysis was performed using TREE-PUZZLE software (Schmidt et al., 2002). Bootstrap analysis was performed to provide confidence estimates for the phylogenetic tree topologies. The phylogenetic tree indicated that strain $\mathrm{GO} 25^{\mathrm{T}}$ formed a clade with an Alviniconcha sp. gill symbiont, deeply branched prior to the divergence of Sulfurimonas autotrophica $\mathrm{OK}_{10}^{\mathrm{T}}$ (Inagaki et al., 2003) and Thiomicrospira denitrificans DSM $1251^{\mathrm{T}}$ (Brinkhoff et al., 2005; Kuenen et al., 1991; Timmer-ten Hoor, 1975) (Fig. 2). Both the sequence similarity analysis and phylogenetic analysis suggested that strain $\mathrm{GO} 25^{\mathrm{T}}$ belonged to the genus Sulfurimonas.

DNA-DNA hybridization between genomic DNA of strain $\mathrm{GO} 25^{\mathrm{T}}$ and Sulfurimonas autotrophica $\mathrm{OK} 10^{\mathrm{T}}$ was carried out at $42^{\circ} \mathrm{C}$ for $3 \mathrm{~h}$ and was measured fluorometrically using photobiotin according to the method of Ezaki et al. (1989). The mean hybridization value was $32.4 \%$, indicating that strain $\mathrm{GO} 25^{\mathrm{T}}$ could be differentiated genotypically from Sulfurimonas autotrophica $\mathrm{OK} 10^{\mathrm{T}}$, according to the definition of a species based on DNA-DNA relatedness (Wayne et al., 1987).

\section{Enzyme and genetic features of energy and carbon metabolisms}

Potential key enzyme activities for chemolithoautotrophic growth of strain $\mathrm{GO} 25^{\mathrm{T}}$ (ATP-dependent citrate lyase, pyruvate: acceptor oxidoreductase, 2-oxoglutarate: acceptor oxidoreductase, isocitrate dehydrogenase, phosphoenolpyruvate carboxylase, pyruvate carboxylase, ribulose1,5-bisphosphate carboxylase/oxygenase, hydrogenase, thiosulfate-oxidizing enzymes, adenosine $5^{\prime}$-phosphate sulfate reductase and sulfite oxidoreductase) were examined as reported previously (Takai et al., 2005b). Genes for key enzymes of inorganic carbon fixation and $\mathrm{H}_{2}$ oxidation were also determined as described previously (Takai et al., 2005b). Strain GO25 $5^{\mathrm{T}}$ had key enzyme activities for a reductive TCA cycle (ATP-dependent citrate lyase, pyruvate: acceptor oxidoreductase, 2-oxoglutarate: acceptor oxidoreductase and isocitrate dehydrogenase) but not for the Calvin-Benson cycle and possessed enzymes involved in $\mathrm{H}_{2}$ and $\mathrm{S}^{0}$ oxidation (hydrogenase and sulfite oxidoreductase) (Takai et al., 2005b). In addition, genes for the enzymes ATP-dependent citrate lyase $(a c l B)$, pyruvate:acceptor oxidoreductase (por $A B)$, 2-oxoglutarate:acceptor oxidoreductase $($ oor $A B)$ and hydrogenase (hynSL) were identified in the genome of strain $\mathrm{GO}^{2} 5^{\mathrm{T}}$ (Takai et al., 2005b). These were clear enzyme and genetic signatures for the $\mathrm{H}_{2}$ - and $\mathrm{S}^{0}$-oxidizing chemolithoautotrophy of strain $\mathrm{GO} 25^{\mathrm{T}}$.

\section{Comparison with related species}

Strain $\mathrm{GO} 25^{\mathrm{T}}$ is a mesophilic, facultatively anaerobic, strict chemolithoautotroph using $\mathrm{H}_{2}$ or reduced sulfur compounds as the sole energy source. This strain is the first described strain of deep-sea epsilonproteobacteria that is capable of utilizing both $\mathrm{H}_{2}$ and reduced sulfur compounds as energy sources and only the second reported epsilonproteobacterium to do so, after Sulfuricurvum kujiense YK- $1^{\mathrm{T}}$, isolated from an underground crude-oil storage cavity in Japan (Kodama \& Watanabe, 2004). Phylogenetic analysis indicated that strain $\mathrm{GO} 25^{\mathrm{T}}$ is most closely related to Sulfurimonas autotrophica $\mathrm{OK} 10^{\mathrm{T}}$, isolated from deep-sea hydrothermal sediments at Hatoma Knoll in the Okinawa Trough (Inagaki et al., 2003; Takai et al., 2003) (Fig. 2). However, many of the physiological characteristics of strain $\mathrm{GO} 25^{\mathrm{T}}$ are different from those of Sulfurimonas autotrophica $\mathrm{OK} 10^{\mathrm{T}}$ (Table 1). The utilization patterns of both electron donors and electron acceptors are different and the optimal growth conditions also differ between the two strains (Table 1). Major cellular fatty acid content is a chemotaxonomic feature that can differentiate the two strains. In addition, DNA-DNA hybridization analysis clearly indicates that strain $\mathrm{GO} 25^{\mathrm{T}}$ can be differentiated genotypically from Sulfurimonas autotrophica $\mathrm{OK} 10^{\mathrm{T}}$ at the species level.

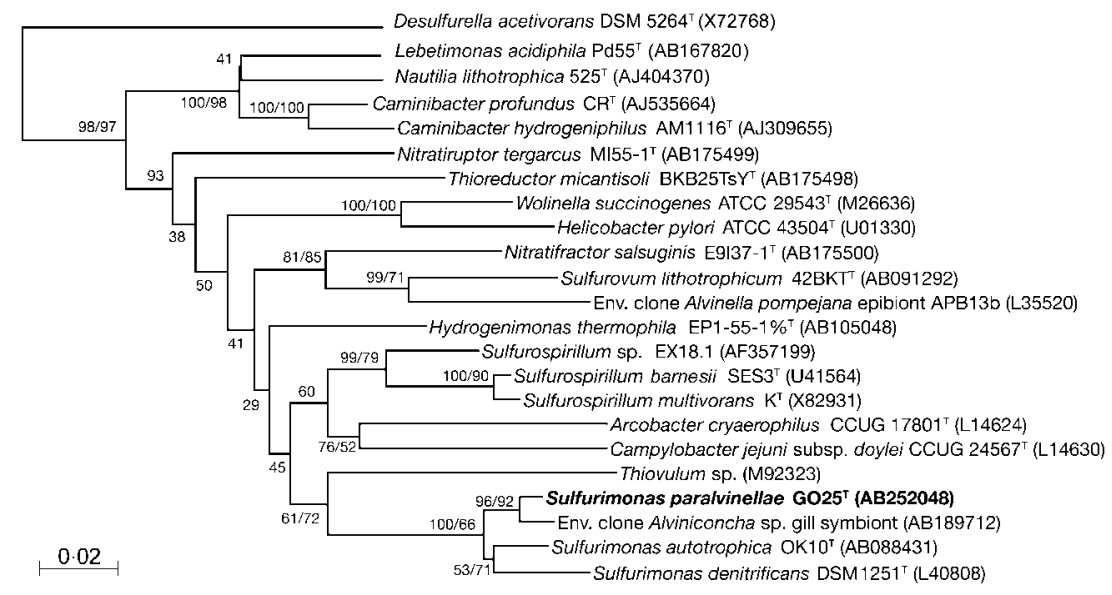

Fig. 2. Phylogenetic tree of representative epsilonproteobacteria and environmental rRNA gene clones inferred from 16S rRNA gene sequences using the neighbour-joining method on 1051 homologous sequence positions for each organism. Numbers at each node represent bootstrap values (as a percentage) determined from 1000 replicates (neighbour-joining tree/maximumlikelihood tree). Two numbers are indicated where identical topology is given by the two trees, while only one number represents the bootstrap value by the neighbour-joining treeing method. Bar, 2 substitutions per 100 nucleotides. 
On the basis of these physiological and genetic properties, we propose that strain $\mathrm{GO} 25^{\mathrm{T}}$ represents the type strain of a novel species of the genus Sulfurimonas, Sulfurimonas paralvinellae sp. nov.

\section{Ecological implications}

Strain $\mathrm{GO}_{2} 5^{\mathrm{T}}$ grows on both $\mathrm{H}_{2}$ and reduced sulfur compounds as energy sources. However, in this study, it was demonstrated that $\mathrm{H}_{2}$ provided a higher growth rate for strain $\mathrm{GO} 25^{\mathrm{T}}$ than reduced sulfur compounds and that $\mathrm{H}_{2}$ was predominantly utilized even though excess amounts of reduced sulfur compounds were also present. This is a very important clue to understanding the energy metabolism of strain $\mathrm{GO} 25^{\mathrm{T}}$ in situ in its habitat of polychaete nests. The polychaete colonies at NBC in the Iheya North field are situated adjacent to hydrothermal fluid ventings (Nakagawa et al., 2005c). Due to their close proximity to hydrothermal fluids, considerable amounts of both $\mathrm{H}_{2}$ and reduced sulfur compounds are likely to be present in the habitat. However, according to the typical hydrothermal fluid chemistries in the Okinawa Trough, the concentration of $\mathrm{H}_{2} \mathrm{~S}$ is approximately two orders of magnitude higher than that of $\mathrm{H}_{2}$ in the hydrothermal fluids (Gamo, 1995). In addition, it has been noted that the polychaete nests are covered with elemental sulfur particles, probably formed by chemical and microbiological processes. This implies that reduced sulfur compounds are always much more accessible and available than $\mathrm{H}_{2}$ as energy sources for strain $\mathrm{GO} 25^{\mathrm{T}}$ in situ. Considering the higher growth rate observed with $\mathrm{H}_{2}$ compared with reduced sulfur compounds and the preferred utilization of $\mathrm{H}_{2}$ coincident with more abundant reduced sulfur compounds shown in this study, strain $\mathrm{GO} 25^{\mathrm{T}}$ may be sustained primarily by smaller amounts of $\mathrm{H}_{2}$ as the energy source in situ. Although versatile energy metabolism using a variety of electron donor and acceptor species is a key feature of the deep-sea epsilonproteobacteria, it has been demonstrated that hydrogen-oxidizing chemolithoautotrophy is more common than sulfur-oxidizing forms among deep-sea epsilonproteobacterial isolates from various deep-sea hydrothermal vent niches (Nakagawa et al., 2005c). Further kinetic analyses of growth, using a variety of combinations and varying concentrations of electron donor and acceptor species, and determination of the molecular basis of biochemical characterizations will aid in the elucidation of the in situ energy metabolism of deep-sea epsilonproteobacteria showing versatile chemolithoautotrophy, such as strain $\mathrm{GO} 25^{\mathrm{T}}$, in complex and diverse deep-sea hydrothermal vent habitats.

\section{Reclassification of Thiomicrospira denitrificans}

Thiomicrospira denitrificans DSM $1251^{\mathrm{T}}\left(=\right.$ ATCC $33889^{\mathrm{T}}$ ) (Brinkhoff et al., 2005; Kuenen et al., 1991; Timmer-ten Hoor, 1975) is phylogenetically associated with Sulfurimonas autotrophica $\mathrm{OK} 10^{\mathrm{T}}$ and strain $\mathrm{GO} 25^{\mathrm{T}}$ (Fig. 2). This bacterium was isolated from coastal marine sediments with an interface between oxygen and sulfide and is a mesophilic, neutrophilic, facultatively anaerobic, denitrifying chemolithoautotroph that uses sulfide or thiosulfate and nitrate or nitrite as the electron donor and acceptor (Brinkhoff et al., 2005; Kuenen et al., 1991; Timmer-ten Hoor, 1975). The genus Thiomicrospira (type species Thiomicrospira pelophila) was proposed for a group of sulfuroxidizing micro-organisms (Kuenen \& Veldkamp, 1972). Muyzer et al. (1995) suggested that this group belonged within the Gammaproteobacteria. It has often been pointed out that $T$. denitrificans, an epsilonproteobacterium, should be reclassified and renamed (Brinkhoff et al., 2005; Takai et al., 2004d). As shown in Table 1, many physiological properties of $T$. denitrificans DSM $1251^{\mathrm{T}}$, particularly the utilization pattern of electron donors and acceptors, are different from those of Sulfurimonas autotrophica OK $10^{\mathrm{T}}$ and/or strain GO25 $5^{\mathrm{T}}$. However, differences in physiological properties have also been found between Sulfurimonas autotrophica $\mathrm{OK} 10^{\mathrm{T}}$ and strain $\mathrm{GO} 25^{\mathrm{T}}$. Nakagawa et al. (2005c) clearly demonstrated that the metabolic versatility of deep-sea epsilonproteobacteria is not relevant to their $16 \mathrm{~S}$ rRNA gene phylogeny. Thus, differences in metabolic traits might not always be a good marker for the classification of taxa within the Epsilonproteobacteria. The 16S rRNA gene sequence of T. denitrificans DSM $1251^{\mathrm{T}}$ has $93 \cdot 3$ and $93 \cdot 1 \%$ similarity with those of Sulfurimonas autotrophica OK $10^{\mathrm{T}}$ and strain $\mathrm{GO} 25^{\mathrm{T}}$, respectively; these values fall within the range of $16 \mathrm{~S}$ rRNA gene sequence similarity recognized for differentiation at the genus level (90-96\%) (Gillis et al., 2001). However, the phylogenetic relationship among $T$. denitrificans DSM $1251^{\mathrm{T}}$, Sulfurimonas autotrophica $\mathrm{OK} 10^{\mathrm{T}}$ and strain $\mathrm{GO} 25^{\mathrm{T}}$, as indicated in Fig. 2, suggests that $T$. denitrificans DSM $1251^{\mathrm{T}}$ should be recognized as a member of the genus Sulfurimonas. Therefore, primarily based on the phylogenetic relationship, we propose the reclassification of Thiomicrospira denitrificans as Sulfurimonas denitrificans comb. nov.

\section{Emended description of the genus Sulfurimonas}

Cells are Gram-negative and morphologically variable. Straight to slightly short rods, elongated rods and spiral in different growth phases and under different growth conditions. Mesophilic and facultatively anaerobic. Do not always require $\mathrm{NaCl}$ for growth. Growth occurs chemolithoautotrophically with sulfide, $\mathrm{S}^{0}$, thiosulfate and $\mathrm{H}_{2}$ as electron donors and with nitrate, nitrite and $\mathrm{O}_{2}$ as electron acceptors, using $\mathrm{CO}_{2}$ as a carbon source. Potential ecological niches are deep-sea hydrothermal environments and marine sulfidic environments. The type species is Sulfurimonas autotrophica (Inagaki et al., 2003).

\section{Description of Sulfurimonas paralvinellae sp. nov.}

Sulfurimonas paralvinellae (pa.ral.vi.nell'ae. N.L. gen. n. paralvinellae of Paralvinella, a genus of annelid polychaetes from which the organism was first isolated).

Each cell is a motile rod with a polar flagellum, $1 \cdot 5-2 \cdot 5 \mu \mathrm{m}$ long and approximately $0 \cdot 6-0 \cdot 8 \mu \mathrm{m}$ wide. Cells occur 
singly. Gram-negative. Anaerobic to microaerobic (up to $10 \%$ partial pressure of $\mathrm{O}_{2}$ ). Temperature range for growth is $4-35^{\circ} \mathrm{C}$, optimum is $30^{\circ} \mathrm{C}$. The $\mathrm{pH}$ range for growth is $5 \cdot 4-8 \cdot 6$, with an optimum at $\mathrm{pH} 6 \cdot 1 . \mathrm{NaCl}$ is required for growth at 12-50 $\mathrm{g} \mathrm{l}^{-1}$; optimum growth occurs at $30 \mathrm{~g} \mathrm{l}^{-1}$. Strictly chemolithoautotrophic growth occurs with $\mathrm{H}_{2}, \mathrm{~S}^{0}$ or thiosulfate as an electron donor and with nitrate or $\mathrm{O}_{2}$ as an electron acceptor. Nitrate is reduced to nitrite, $\mathrm{N}_{2} \mathrm{O}$ and $\mathrm{N}_{2}$ during growth. Elemental sulfur, thiosulfate or yeast extract serves as a sulfur source for growth. Nitrate or ammonium is required as a nitrogen source. Vitamins, selenium and tungsten are not required for growth. The major cellular fatty acids are $\mathrm{C}_{18: 1}(37 \%), \mathrm{C}_{16: 0}(25 \%), \mathrm{C}_{16: 1}(22 \%)$, $3-\mathrm{OH} \mathrm{C} \mathrm{C}_{14: 0}(7 \%), \mathrm{C}_{14: 0}(5 \%)$ and $\mathrm{C}_{18: 0}(4 \%)$. The DNA $\mathrm{G}+\mathrm{C}$ content is $37 \cdot 6 \mathrm{~mol} \%$ (by HPLC).

The type strain, strain $\mathrm{GO} 25^{\mathrm{T}}\left(=\mathrm{JCM} 13212^{\mathrm{T}}=\mathrm{DSM}\right.$ $17229^{\mathrm{T}}$ ), was isolated from a polychaete nest of Paralvinella sp. at the Iheya North Field in the Mid-Okinawa Trough.

\section{Description of Sulfurimonas denitrificans comb. nov.}

Sulfurimonas denitrificans (de.ni.tri'fi.cans. N.L. v. denitrifico to denitrify; N.L. part. adj. denitrificans denitrifying).

Basonym: Thiomicrospira denitrificans Timmer-ten Hoor 1975 (Approved Lists 1980).

The description remains as given by Brinkhoff et al. (2005). The type strain is DSM $1251^{\mathrm{T}}$ (=ATCC $33889^{\mathrm{T}}$ ).

\section{Acknowledgements}

We would like to thank Dr Katsuyuki Uematsu for assistance in preparing electron micrographs. We are very grateful to the $\mathrm{R} / \mathrm{V}$ Natsushima and the Shinkai 2000 operation teams for helping us to collect deep-sea hydrothermal vent samples.

\section{References}

Alain, K., Querellou, J., Lesongeur, F., Pignet, P., Crassous, P., Raguenes, G., Cueff, V. \& Cambon-Bonavita, M. A. (2002). Caminibacter hydrogeniphilus gen. nov., sp. nov., a novel thermophilic, hydrogen-oxidizing bacterium isolated from an East Pacific Rise hydrothermal vent. Int J Syst Evol Microbiol 52, 1317-1323.

Allen, S. E., Grimshaw, H. M., Parkinson, J. A. \& Quarmby, C. (1974). Inorganic constituents: nitrogen. In Chemical Analysis of Ecological Materials, pp. 184-206. Edited by S. E. Allen. London: Blackwell Scientific.

Altschul, S. F., Madden, T. L., Schäffer, A. A., Zhang, J., Zhang, Z., Miller, W. \& Lipman, D. J. (1997). Gapped BLAST and PSI-BLAST: a new generation of protein database search programs. Nucleic Acids Res 25, 3389-3402.

Balch, W. E., Fox, G. E., Magrum, L. J., Woese, C. R. \& Wolfe, R. S. (1979). Methanogens: reevaluation of a unique biological group. Microbiol Rev 43, 260-296.

Benson, D. A., Boguski, M. S., Lipman, D. J., Ostell, J. \& Ouellette, B. F. F. (1998). GenBank. Nucleic Acids Res 26, 1-7.
Brinkhoff, T., Kuever, J., Muyzer, G. \& Jannasch, H. W. (2005). Genus VI. Thiomicrospira. In Bergey's Manual of Systematic Bacteriology, 2nd edn, vol. 2, part B, pp. 193-199. Edited by D. J. Brenner, N. R. Krieg \& J. T. Staley. New York: Springer.

Campbell, B. J., Jeanthon, C., Kostka, J. E., Luther, G. W., III \& Cary, S. C. (2001). Growth and phylogenetic properties of novel bacteria belonging to the epsilon subdivision of the Proteobacteria enriched from Alvinella pompejana and deep-sea hydrothermal vents. Appl Environ Microbiol 67, 4566-4572.

DeLong, E. F. (1992). Archaea in coastal marine environments. Proc Natl Acad Sci U S A 89, 5685-5689.

Ezaki, T., Hashimoto, Y. \& Yabuuchi, E. (1989). Fluorometric deoxyribonucleic acid-deoxyribonucleic acid hybridization in microdilution wells as an alternative to membrane filter hybridization in which radioisotopes are used to determine genetic relatedness among bacterial strains. Int J Syst Bacteriol 39, 224-229.

Gamo, T. (1995). Wide variation of chemical characteristics of submarine hydrothermal fluids due to secondary modification process after high temperature water-rock interaction: a review. In Biogeochemical Processes and Ocean Flux in the Western Pacific, pp. 425451. Edited by H. Sakai \& Y. Nozaki. Tokyo: Terra Scientific Publishing.

Gillis, M., Vandamme, P., De Vos, P., Swings, J. \& Kerster, K. (2001). Polyphasic taxonomy. In Bergey's Manual of Systematic Bacteriology, 2nd edn, vol.1, pp. 43-48. Edited by D. R. Boone, R. W. Castenholz \& G. M. Garity. London: Springer.

Hügler, M., Wirsen, C. O., Fuchs, G., Taylor, C. D. \& Sievert, S. M. (2005). Evidence for autotrophic $\mathrm{CO}_{2}$ fixation via the reductive tricarboxylic acid cycle by members of the $\varepsilon$ subdivision of Proteobacteria. J Bacteriol 187, 3020-3027.

Inagaki, F., Takai, K., Kobayashi, H., Nealson, K. H. \& Horikoshi, K. (2003). Sulfurimonas autotrophica gen. nov., sp. nov., a novel sulfuroxidizing $\varepsilon$-proteobacterium isolated from hydrothermal sediments in the Mid-Okinawa Trough. Int J Syst Evol Microbiol 53, 1801-1805.

Inagaki, F., Takai, K., Nealson, K. H. \& Horikoshi, K. (2004). Sulfurovum lithotrophicum gen. nov., sp. nov., a novel sulfur-oxidizing chemolithoautotroph within the $\varepsilon$-Proteobacteria isolated from Okinawa Trough hydrothermal sediments. Int J Syst Evol Microbiol 54, 1477-1482.

Kodama, Y. \& Watanabe, K. (2004). Sulfuricurvum kujiense gen. nov., sp. nov., a facultatively anaerobic, chemolithoautotrophic, sulfuroxidizing bacterium isolated from an underground crude-oil storage cavity. Int J Syst Evol Microbiol 54, 2297-2300.

Kuenen, J. G. \& Veldkamp, H. (1972). Thiomicrospira pelophila, gen. n., sp. n., a new obligately chemolithotrophic colourless sulfur bacterium. Antonie van Leeuwenhoek 38, 241-256.

Kuenen, J. G., Robertson, L. A. \& Tuovinen, O. H. (1991). The genera Thiobacillus, Thiomicrospira, and Thiosphaera. In The Prokaryotes, 2nd edn, pp. 2638-2657. Edited by A. Balows, H. G. Trüper, M. Dworkin, W. Harder \& K. H. Schleifer. New York: Springer.

Lane, D. J. (1991). 16S/23S rRNA sequencing. In Nucleic Acid Techniques in Bacterial Systematics, pp. 115-176. Edited by E. Stackbrandt \& M. Goodfellow. New York: Wiley.

Ludwig, W., Strunk, O., Westram, R. \& 28 other authors (2004). ARB: a software environment for sequence data. Nucleic Acids Res 32, 1363-1371.

Marmur, J. \& Doty, P. (1962). Determination of the base composition of deoxyribonucleic acid from its thermal denaturation temperature. J Mol Biol 5, 109-118.

Miroshnichenko, M. L., Kostrikina, N. A., L'Haridon, S., Jeanthon, C., Hippe, H., Stackebrandt, E. \& Bonch-Osmolovskaya, E. A. (2002). Nautilia lithotrophica gen. nov., sp. nov., a thermophilic sulfurreducing epsilon-proteobacterium isolated from a deep-sea hydrothermal vent. Int J Syst Evol Microbiol 52, 1299-1304. 
Miroshnichenko, M. L., L'Haridon, S., Schumann, P., Spring, S., Bonch-Osmolovskaya, E. A., Jeanthon, C. \& Stackebrandt, E. (2004). Caminibacter profundus sp. nov., a novel thermophile of Nautiliales ord. nov. within the class 'Epsilonproteobacteria', isolated from a deep-sea hydrothermal vent. Int J Syst Evol Microbiol 54, $41-45$.

Muyzer, G., Teske, A., Wirsen, C. O. \& Jannasch, H. W. (1995). Phylogenetic relationships of Thiomicrospira species and their identification in deep-sea hydrothermal vent samples by denaturing gradient gel electrophoresis of $16 \mathrm{~S}$ rDNA fragments. Arch Microbiol 164, 165-172.

Nakagawa, S., Inagaki, F., Takai, K., Horikoshi, K. \& Sako, Y. (2005a). Thioreductor micantisoli gen. nov., sp. nov., a novel mesophilic, sulfur-reducing chemolithoautotroph within the $\varepsilon$-Proteobacteria isolated from the hydrothermal sediments in the Mid-Okinawa Trough. Int J Syst Evol Microbiol 55, 599-605.

Nakagawa, S., Takai, K., Inagaki, F., Horikoshi, K. \& Sako, Y. (2005b). Nitratiruptor tergarcus gen. nov., sp. nov. and Nitratifractor salsuginis gen. nov., sp. nov., nitrate-reducing chemolithoautotrophs of the $\varepsilon$-Proteobacteria isolated from a deep-sea hydrothermal system in the Mid-Okinawa Trough. Int J Syst Evol Microbiol 55, 925-933.

Nakagawa, S., Takai, K., Inagaki, F., Hirayama, H., Nunoura, T., Horikoshi, K. \& Sako, Y. (2005c). Distribution, phylogenetic diversity and physiological characteristics of epsilon-Proteobacteria in a deep-sea hydrothermal field. Environ Microbiol 7, 1619-1632.

Porter, K. G. \& Feig, Y. S. (1980). The use of DAPI for identifying and counting aquatic microflora. Limnol Oceanogr 25, 943-948.

Schmidt, H. A., Strimmer, K., Vingron, M. \& von Haeseler, A. (2002). TREE-PUZZLE: maximum likelihood phylogenetic analysis using quartets and parallel computing. Bioinformatics 18, 502-504.

Suzuki, Y., Sasaki, T., Suzuki, M., Nogi, Y., Miwa, T., Takai, K., Nealson, K. H. \& Horikoshi, K. (2005). Novel chemoautotrophic endosymbiosis between a member of the epsilonproteobacteria and the hydrothermal-vent gastropod Alviniconcha aff. hessleri (Gastropoda: Provannidae) from the Indian Ocean. Appl Environ Microbiol 71, 5440-5450.

Takai, K. \& Horikoshi, K. (2000). Thermosipho japonicus sp. nov., an extremely thermophilic bacterium isolated from a deep-sea hydrothermal vent in Japan. Extremophiles 4, 9-17.

Takai, K., Komatsu, T. \& Horikoshi, K. (2001). Hydrogenobacter subterraneus sp. nov., an extremely thermophilic, heterotrophic bacterium unable to grow on hydrogen gas, from deep subsurface geothermal water. Int J Syst Evol Microbiol 51, 1425-1435.

Takai, K., Inagaki, F., Nakagawa, S., Hirayama, H., Nunoura, T., Sako, Y., Nealson, K. H. \& Horikoshi, K. (2003). Isolation and phylogenetic diversity of members of previously uncultivated $\varepsilon$-Proteobacteria in deep-sea hydrothermal fields. FEMS Microbiol Lett 218, 167-174.

Takai, K., Gamo, T., Tsunogai, U., Nakayama, N., Hirayama, H., Nealson, K. H. \& Horikoshi, K. (2004a). Geochemical and microbiological evidence for a hydrogen-based, hyperthermophilic subsurface lithoautotrophic microbial ecosystem (HyperSLiME) beneath an active deep-sea hydrothermal field. Extremophiles 8, 269-282.

Takai, K., Oida, H., Suzuki, Y., Hirayama, H., Nakagawa, S., Nunoura, T., Inagaki, F., Nealson, K. H. \& Horikoshi, K. (2004b). Spatial distribution of marine crenarchaeota group I in the vicinity of deep-sea hydrothermal systems. Appl Environ Microbiol 70, 2404-2413.

Takai, K., Nealson, K. H. \& Horikoshi, K. (2004c). Hydrogenimonas thermophila gen. nov., sp. nov., a novel thermophilic, hydrogenoxidizing chemolithoautotroph within the $\varepsilon$-Proteobacteria, isolated from a black smoker in a Central Indian Ridge hydrothermal field. Int J Syst Evol Microbiol 54, 25-32.

Takai, K., Hirayama, H., Nakagawa, T., Suzuki, Y., Nealson, K. H. \& Horikoshi, K. (2004d). Thiomicrospira thermophila sp. nov., a novel microaerobic, thermotolerant, sulfur-oxidizing chemolithomixotroph isolated from a deep-sea hydrothermal fumarole in the TOTO caldera, Mariana Arc, Western Pacific. Int J Syst Evol Microbiol 54, 2325-2333.

Takai, K., Hirayama, H., Nakagawa, T., Suzuki, Y., Nealson, K. H. \& Horikoshi, K. (2005a). Lebetimonas acidiphila gen. nov., sp. nov., a novel thermophilic, acidophilic, hydrogen-oxidizing chemolithoautotroph within the 'Epsilonproteobacteria', isolated from a deep-sea hydrothermal fumarole in the Mariana Arc. Int J Syst Evol Microbiol 55, 183-189.

Takai, K., Campbell, B. J., Cary, S. C. \& 8 other authors (2005b). Enzymatic and genetic characterization of carbon and energy metabolisms by deep-sea hydrothermal chemolithoautotrophic isolates of Epsilonproteobacteria. Appl Environ Microbiol 71, 7310-7320.

Tamaoka, J. \& Komagata, K. (1984). Determination of DNA base composition by reversed-phase high-performance liquid chromatography. FEMS Microbiol Lett 25, 125-128.

Timmer-ten Hoor, A. (1975). A new type of thiosulphate oxidizing, nitrate reducing microorganisms: Thiomicrospira denitrificans sp. nov. Neth J Sea Res 9, 344-350.

Urakawa, H., Dubilier, N., Fujiwara, Y., Cunningham, D. E., Kojima, S. \& Stahl, D. A. (2005). Hydrothermal vent gastropods from the same family (Provannidae) harbour $\varepsilon$ - and $\gamma$-proteobacterial endosymbionts. Environ Microbiol 7, 750-754.

Voordeckers, J. W., Starovoytov, V. \& Vetriani, C. (2005). Caminibacter mediatlanticus sp. nov., a thermophilic, chemolithoautotrophic, nitrate-ammonifying bacterium isolated from a deep-sea hydrothermal vent on the Mid Atlantic Ridge. Int J Syst Evol Microbiol 55, 773-779.

Wayne, L. G., Brenner, D. J., Colwell, R. R. \& 9 other authors (1987). International Committee on Systematic Bacteriology. Report of the ad hoc committee on reconciliation of approaches to bacterial systematics. Int J Syst Bacteriol 37, 463-464.

Zillig, W., Holz, I., Janekovic, D. \& 7 other authors (1990). Hyperthermus butylicus, a hyperthermophilic sulfur-reducing archaebacterium that ferments peptides. J Bacteriol 172, 3959-3965. 